EXEMPLARIa Classica

Journal of Classical Philology

17, 2013, pp. 5-26

ISSN 1699-3225

\title{
A LA BÚSQUEDA DE LA ARMONÍA CÍVICA PERDIDA: EROS, AFRODITA Y LA REFORMULACIÓN DRAMÁTICA EN LAS TRAGEDIAS TARDÍAS DE SÓFOCLES*
}

\author{
Carmen Morenilla Talens \\ Universidad de Valencia \\ carmen.morenilla@uv.es
}

\section{SUMMARY}

En las últimas tragedias de Sófocles hay un replanteamiento de sus posiciones, perceptible en la reconfiguración de sus carácteres y en su relación con los dioses. En Antígona y Traquinias, obras tempranas, a través de sus coros vemos las diferentes formas de concreción de Eros-Afrodita. En Edipo en Colono se sirve otra vez de Afrodita, pero en una forma y sentido singulares.

KEYWORDS

Tragedia Griega, Sófocles, Eros, Afrodita, reformulación dramática.

\section{RESUMEN}

In Sophocles' latest tragedies there is a reassessment of his positions. It is especially remarkable in the reworking of their characters and in the relationship between them and the gods. Throughout the chorus of early tragedies like Antigone and Trachiniae, the patterns of the Eros-Aphrodite relationship can be identified. In Oedipus Coloneus, he uses again Aphrodite, but in a different way and sense.

Palabras Clave

Greek Tragedy, Sophocles, Eros, Aphrodite, dramatic reworking

Fecha de recepción: 13/03/2013

Fecha de aceptación y versión final: 11/07/2013

En la fase final de la producción de Sófocles se puede observar un replanteamiento de sus posiciones anteriores, algo especialmente perceptible en el Filoctetes y, finalmente, en el Edipo en Colono. Con ello Sófocles da testimonio de un cambio en la percepción de la realidad que se traduce en una reformulación del conflicto trágico desarrollado en obras anteriores y en la forma en que éste se dramatiza. Esto es especialmente visible en la relación de su tragedia con los dioses y también en la reconfiguración e integración de sus personajes en la acción dramática. En lo que hace a la relación de

* El presente trabajo se enmarca en el Proyecto de Investigación FFI2012-32071, de la Dirección General de Investigación del Ministerio de Economía y Competitividad de España. 
su tragedia con los dioses, lo vemos, por un lado, en la forma en que éstos intervienen y el nivel de su intervención, pues sólo en dos de las tragedias conservadas lo hacen de forma directa y personal, Atenea en la primera parte del Ayante, Heracles al final del Filoctetes; por otro, en el tratamiento de Eros y Afrodita, presentes de forma plena en sus tragedias, y también, y en relación con ello, aunque indirectamente, en el tratamiento de que es objeto Atenea, la divinidad poliádica ateniense. Y en lo que hace a la reconfiguración e integración de sus personajes, lo vemos en Filoctetes y también en la que es su tragedia postrera, Edipo en Colono, en el establecimiento de un punto de contacto entre el plano humano y el divino centrado en la persona de Edipo.

Sófocles, un autor entre cuyas características se encuentra la de ser moderado en la expresión de las pasiones, en dos tragedias de las consideradas tempranas, Antígona y Traquinias, a través de sus coros fundamentalmente nos habla de un poder capaz de subyugar a hombres y a dioses, un poder que, desdoblado en la dualidad Eros y Afrodita ${ }^{1}$, subyace como motivación primigenia en todos los seres y en la propia naturaleza, y lo hace desarrollando esa dualidad, presentándonos las diferentes formas en las que halla expresión. Y en Edipo en Colono a través del coro introduce de nuevo a Afrodita, pero de una forma y en un sentido singulares: se trata de un canto coral que tiene un precedente en Medea de Eurípides, con notables puntos de contacto y con no menos notables diferencias, y que pueden ayudarnos en su comprensión.

En Antígona, tras la discusión entre padre e hijo, en la que Creonte, ahondando en su ceguera, le ha reprochado a su hijo Hemón que, al insistir en la defensa de la postura de Antígona, se está dejando llevar por su amor hacia la joven ${ }^{2}$, el coro entona el famoso Himno a Eros, un breve canto que en forma

${ }^{1}$ La tematica erótica en la tragedia ha sido objeto de numerosos estudios, cf. el ya clásico J. de Romilly, "L'excuse de l'invincible amour dans la tragédie grecque", en J.M. Bremer \& alii (eds.), Misc. trag. in hon. Kamerbeek, Amsterdam 1976, 309-21, o trabajos más recientes, como el de G. Paduano, "Représentation et interdiction de l'amour chez Euripide", Pallas 38, 1992, 259-65, el de J.P. Serra, "Presenças de Eros em Ésquilo", Humanitas (Coimbra) 54, 2002, 35-48, o el de Ma I. Saravia, "La presencia de Eros en la poesía dramática de Sófocles", Classica (Brasil) 20.2, 2007, 167-81, entre otros.

${ }^{2}$ Sin embargo, los argumentos esgrimidos por Hemón son políticos, no personales: el agón gira en torno a la concepción del poder, a su ejercicio y límites, y a la idea de comunidad cívicoreligiosa que es la polis, frente a la cual Creonte muestra hallarse en unos estadios prepolíticos. Ni Hemón ni Antígona aparecen en momento alguno poseídos por la pasión amorosa, algo que, al parecer, sí le sucederá a la Antígona de la tragedia homónima de Eurípides, como ya ha sido señalado, entre otros, por A. Lesky, La tragedia griega, Barcelona 2001, 288. En la Antígona de Sófocles las motivaciones políticas y religiosas se sitúan en primer plano, motivaciones que Eurípides en su Antígona dejará a un lado, como ya señaló U. Albini, en "Le passioni d'amore nelle tragedie greche", PP 58.4, 2003, 257-74, 272-3. La intriga amorosa que, al parecer, desarrollaba Antígona de Eurípides sirvió de inspiración a Astidamante para su Antígona, con la que obtuvo el primer premio en el año 341 a. C. En general, los personajes de Sófocles, al igual que los de Esquilo, no se mueven arrastrados por pasiones desmedidas, algo de lo que se percatará F. W. G. Hegel, quien en sus Lecciones sobre la estética, Madrid 1989, 415, afirma: "La 
de himno ${ }^{3}$ constituye el estásimo tercero, formado por un único par estrófico, 881-790 791-800, un canto al Eros cósmico, el que rige el universo en su conjunto ${ }^{4}$, en la misma línea en la que se manifiesta Esquilo en la trilogía encabezada por Suplicantes, y que es especialmente perceptible en las palabras de Afrodita contenidas en el fr. 44 R. de Danaidas, y, a la par, con la misma finalidad que el estásimo primero de esta tragedia, donde el coro canta la grandeza del ser humano ${ }^{6}$.

Eros y Afrodita se funden aquí, en este canto de Antígona, en la evocación de un impulso complejo que tiene en "las tiernas mejillas de la muchacha",

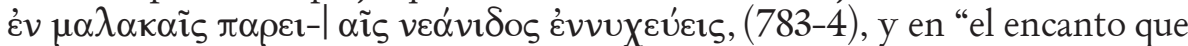

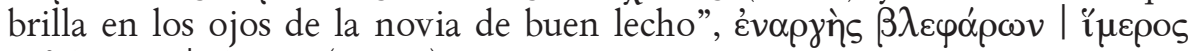

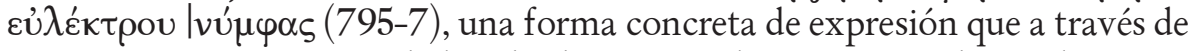
¿ $\mu \varepsilon \rho \varsigma$ se muestra "vinculado a las leyes sagradas que rigen el mundo", $\tau \tilde{\omega} v$

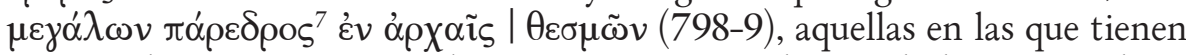
sustento las razones esgrimidas por Hemón con relación al plano general comunitario y las esgrimidas por Antígona con relación al plano particular de los suyos, y uno y otra frente a aquél al que las circunstancias han elevado al

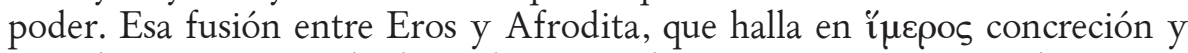
vinculación expresa a las leyes divinas, se hace aún más patente en la respon-

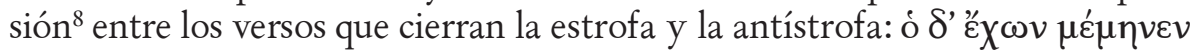

excelsa tragedia de los antiguos tampoco conoce la pasión del amor en su significado romántico. Particularmente en Esquilo y Sófocles no reclama para sí ningún interés esencial”, y ejemplifica Hegel la ausencia de la pasión amorosa en Sófocles con el caso de Hemón en Antígona.

${ }^{3}$ Para la forma que adoptan los himnos cf. el trabajo clásico de E. Norden, Agnostos Theos. Untersuchungen zur Formengeschichte religiöser Rede, Leipzig-Berlin 1913, en especial "Untersuchungen zur Stilgeschichte der Gebets- und Prädikationsformeln", 143ss., y R.E., s.v. Hymnos, coll. 139-83 (Wünsch), sobre el estilo coll. 144-5. Sobre esta relación con los himnos y en general sobre este canto coral, cf. A. Rodighiero, Generi lirico-corali nella produzione drammatica di Sofocle, Göttingen 2012, en particular "Elementi dell'inno nelle tragedie superstiti e corali innodici dell'Antigone: forma e funzione”, 139-65. Véase los procedimientos habituales como reiteraciones ("E

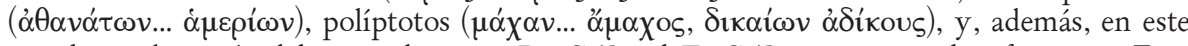
caso la combinación del conocido como Du-Stil y el Er-Stil, puesto que a la referencia a Eros en $3^{a}$ persona, sigue la apelación directa.

${ }^{4}$ Lesky, La tragedia griega, 203; y en un sentido análogo I. Errandonea, en Sófocles y la personalidad de sus coros. Estudio de dramática constructiva, Madrid 1970, 88.

${ }^{5}$ Lesky, La tragedia griega, 207 y 148-9.

${ }^{6}$ Lesky , La tragedia griega, 204-5.

${ }^{7}$ Aquí $\pi \alpha ́ \rho \varepsilon \delta \rho o \varsigma$ se predica de ǐ $\mu \varepsilon \rho \varsigma$, que como expresión de una potencia divina muestra el poder de esa dualidad constituida por Eros y Afrodita. Cf. entre otros, R.P. WinningtonIngram, Sophocles. An Interpretation, Cambridge 1980, 95, n. 13, donde resalta las implicaciones de poder absoluto de este término.

${ }^{8}$ Sobre este género de relaciones establecidas a través de la responsión estrófica, cf. C. Morenilla, "Wort-und Klangresponsion bei Aristophanes", Philologus 131, 1987, 32-49, y de la misma sobre la relación de identidad establecida a través de la responsión estrófica y la alteración emocional, "Wiederkehrende Strukturen und ihre Durchbrechung in der griechischen Tragödie (Aischylos, Sieben gegen Theben; Sophokles, König Oidipus)”, en B. Zimmermann (Hrsg.), 


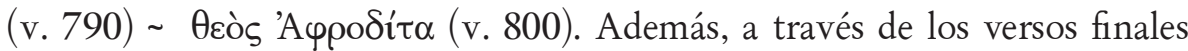

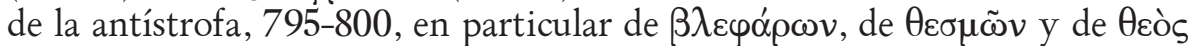
'A $\varphi \rho o \delta i \tau \alpha$, se evoca el proemio de Teogonía, en el que encontramos aquella

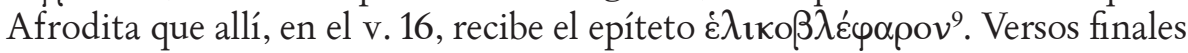
éstos que tienen un carácter conclusivo y que son relevantes para la comprensión de este canto. En ellos se nos dice que Afrodita es $\alpha$ $\mu \alpha \chi o s$, que hace las cosas con gran facilidad, como en un juego de niños, $\dot{\varepsilon} \mu \pi \alpha i^{\prime} \zeta \varepsilon 1^{10}$, con ello se

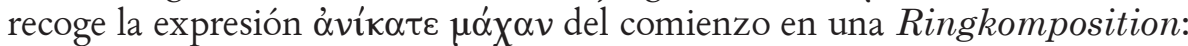

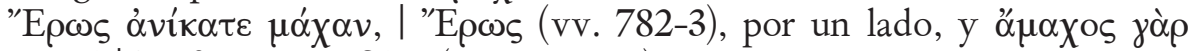

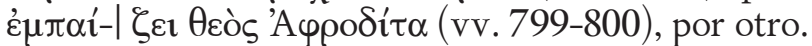

En el estásimo primero es el hombre; ahora, en el tercero, la fuerza primigenia, "Epws, que lo mueve, una fuerza que se extiende por todos los ámbitos,

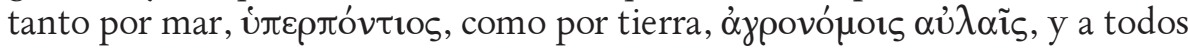
los seres, tanto a las bestias, $\kappa \tau \eta \dot{\mu} \mu \alpha \mathbf{t}^{11}$, como a los inmortales y a los huma-

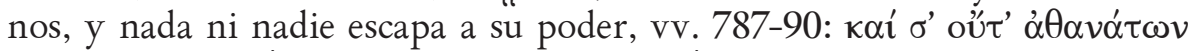

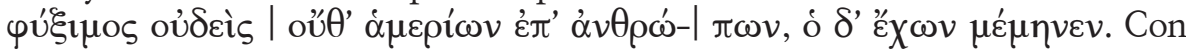
este estásimo tercero, pues, el coro trasciende al plano cósmico lo que en el estásimo primero restringía al plano general del ser humano, y en el segundo, al particular de la casa de Layo. En el centro, pues, en el estásimo segundo, el coro, después de presenciar la discusión entre Antígona y Creonte, en la que ha intervenido con unas palabras no exentas de ironía trágica, vv. 471-2

Griechisch-römische Komödie und Tragödie II, Stuttgart 1997, 95-103.

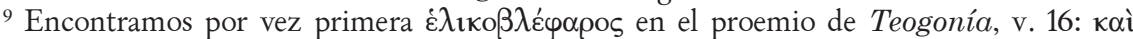

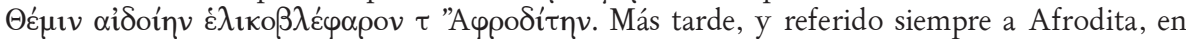
el Himno a Afrodita 6.19, y en Pi. fr. 123 Bergk. Su significado ha sido objeto de discusión;

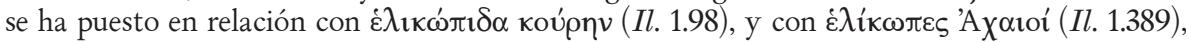

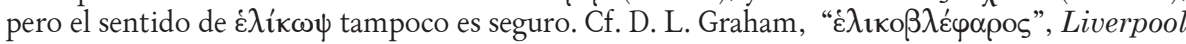
Classical Monthly 11, 1986, 136.

${ }^{10}$ Ese aspecto de Afrodita se irá desplazando hacia Eros, que presentará la forma de un niño al que incluso en la tradición iconográfica veremos reprendido por Afrodita, así, en el dibujo de José de Madrazo, Eros reprendido por Afrodita, Museo del Prado, № de catálogo D06705, de ca. 1812.

${ }^{11}$ El término $\kappa \tau \eta \dot{\mu} \mu \alpha$ ha sido objeto de múltiples interpretaciones, incluso propuestas de modificación, que en parte recoge R. Jebb, Sophocles III. The Antigone, Cambridge 1928 (= 1900³), Appendix, 256-7, P. Chantraine, "Sur l'emploi de $\kappa \tau \eta \dot{\eta} \mu \alpha \tau \alpha$ au sens de bétail, cheptel", $R P h$ 20, 1946, 5-11. Seguimos la interpretación que explica y justifica P. Mazon, Sophocle I. Les Trachiniennes - Antigone, Paris $2005\left(=1994^{7}\right)$.

${ }^{12}$ Son las palabras de Antígona afirmando que sabía lo que hacía y sus consecuencias (vv. 443 y 448), y la célebre rhesis que sigue (vv. 450-70), en abierta oposición a Creonte, lo que mueve al coro a pronunciar estas palabras: Xo. $\delta \eta \lambda$ oi

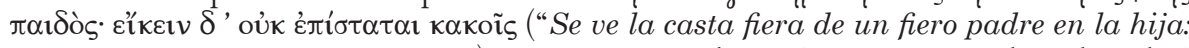
ceder no sabe ante los problemas"). Esta semejanza de Antígona con su padre Edipo dejó honda impronta en el imaginario colectivo hasta el punto de ser recogida por la iconografía; cf. J.V. Bañuls \& P. Crespo, "El vestuario de Antígona: aproximación a una caracterización física del personaje", en Fr. De Martino (ed.), Abiti da Mito, Bari 2008, 257-92. 
que anticipan de forma velada la positivación de Edipo como héroe trágico ${ }^{13}$ en Edipo Rey y en Edipo en Colono, canta la serie de desgracias que como las olas, vv. 586-592, una tras otra han ido golpeando la casa de Layo, vv. 593-603, unas desgracias que ahora cierran su círculo sobre estos personajes, autores y actores de un destino funesto que llega a su final, como anuncian los versos finales, vv. 620-5, que cierran en Ringkomposition, recogiendo en un eco los versos que abren este estásimo segundo, vv. 583-5, versos éstos últimos que nos hablan de la ofuscación del entendimiento que abre el camino a las desgracias, de las que se habla en los versos correspondientes de la antístrofa, y todo ello puesto de relieve por la cursiva fónica y las reiteraciones que subrayan las relaciones a través de la responsión:

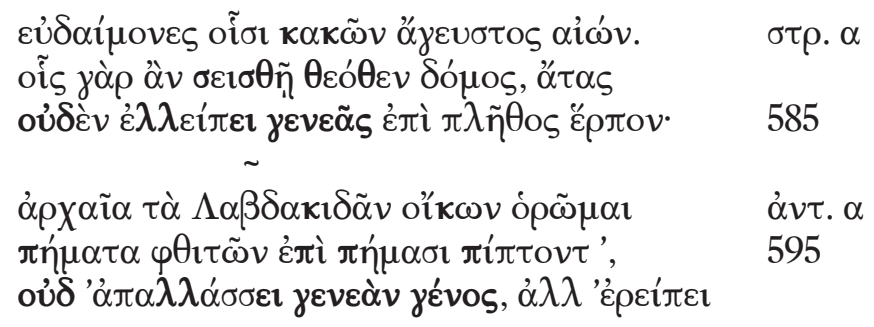

El porqué de las desgracias de la casa de Layo lo encontramos planteado de forma general en el par estrófico que cierra este estásimo segundo, vv. 604-14 615-25, en el que oímos al coro insistir en aquella idea con la que advertía en los versos que cierran el estásimo primero, vv. 365-75: una dualidad alternante e inevitable del bien y del mal que en su discurrir vital el hombre va sembrando y cosechando, cerrándose estrofa y antístrofa por la

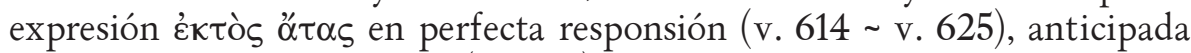
y reforzada por $\pi$ pòs ó $\tau \alpha \nu$ (v. 624). Y tras esa dualidad, expresión de la justicia en la que se ven contrarrestados los más que probables excesos de los hombres, se encuentra Zeus, como con acierto canta el coro de ancianos

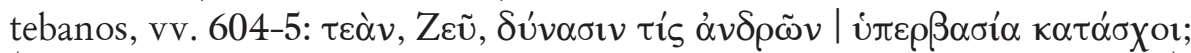
(“¿Tu poderío, Zeus, qué desmesura de los hombres podría someterlo?”). Aquel ser tremendo del que nos habla el primer estásimo, capaz de someter la naturaleza tanto la animada como la no animada, encuentra un poder superior, Zeus, que a su vez no está libre de caer bajo otro poder, el de Eros. Ésta es la gradación que encontramos entre los tres estásimos: el ser humano, Zeus, Eros. Hay, pues, un proceso de concreción que va del primer estásimo al segundo, para elevarse al plano cósmico general en el tercero, en el que el coro con su canto va al origen de todo, a la fuerza primigenia que subyace siempre como motivación primordial. Y todo ello en perfecta armonía con

${ }^{13}$ A este respecto cf. J. V. Bañuls - C. Morenilla, "Rasgos esquileos en la caracterización de algunos personajes sofocleos”, $C F C(G) 18,2008,73-87$. 
la progresión de la acción dramática que ante los ojos del coro discurre hacia un abismo trágico.

Tenemos, pues, por un lado, el tremendo poder del ser humano sobre el entorno y sobre sí mismo, un poder que es presentado en sus aspectos positivos, pero también en los negativos: las desgracias que una tras otra han ido golpeando la casa de Layo; por otro lado, la fuerza primigenia que sustancia ese poder, creadora y a la vez destructora, capaz de elevar a lo más alto al ser humano y a la vez sumirlo en la más completa miseria -y Edipo y su linaje son un claro ejemplo de ello, como los vv. 598-603 del estásimo segundo señalan-, una fuerza que ha llevado la desgracia e incluso la muerte a tantos, al igual que ahora lleva a Antígona, a Hemón y a Eurídice, y al mismo Creonte, una fuerza que está en los orígenes mismos de las desgracias que se han ido abatiendo sobre la casa de Layo, presente en la pasión por Crísipo que dominó a Layo, y que, incapaz de controlarla, le arrastró a violentar la hospitalidad de

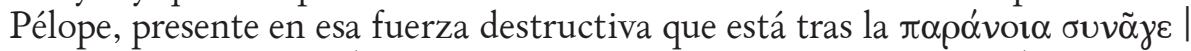

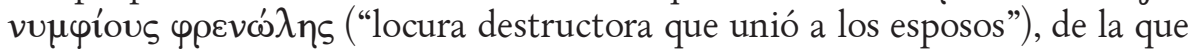
habla el coro de Siete contra Tebas de Esquilo en referencia tanto a Edipo y Yocasta como a ésta última y a Layo, en los vv. 756-7.

La tragedia griega nos sitúa ante el ser humano en toda su complejidad, por ello no hay que buscar una única y simple motivación para sus acciones y reacciones, pues son muchas las que suelen confluir en los personajes moviéndolos en una dirección o en otra, motivaciones que las más de las veces se pueden jerarquizar, pero no disociar. Es innegable que en el ánimo de Hemón debe pesar el hecho de que Antígona sea su prometida, pero mucho más pesa en él el que Creonte sea su padre ${ }^{14} y$, sobre todo, pesa en su ánimo el profundo sentido de la justicia y los valores que informan y sustancian al ciudadano griego, de los que él en el agón con su padre da sobradas muestras ${ }^{15}$.

${ }^{14}$ Esta relación es subrayada por Jebb para explicar las razones por las que Hemón finalmente se da muerte, Sophocles. The Antigone, 219: "Haemon, in his madness, meant to kill his father. He had harboured no such purpose before (see on 753); and his frantic impulse is instantly followed by violent remorse".

${ }^{15}$ Todo ello pesa en el ánimo de Hemón; por ello, las consideraciones al respecto en extremo restrictivas formuladas por H. v. Fritz en "Haimons Liebe zu Antigone”, Philologus 89, 1934, 19-34, aquí 29-30 ("Wenn also Leidenschaft die Triebfeder Haimons sein soll, dann schalte man auch alles Ethische aus seinem Verhalten aus und betrachte ihn als das unglückliche Opfer des Wahnes, mit dem ihn die Götter geschlagen haben. (...) Aus den Motiven Haimons jedenfalls ist eine persönliche Leidenschaft von Anfang bis zu Ende fernzuhalten"), han sido matizadas entre otros por A. Lesky, Die Tragische Dichtung der Hellenen, Göttingen $1972\left(=1963^{3}\right)$, 199 ("K. v. Fritz hat (a.O.) gezeigt, dass dieser Haimon nicht allein der von seiner Liebe Getriebene ist, der die Sorge um die Ehre seines Vaters nur zum Vorwand nimmt. Vorwürfe, die ihm Kreon in diesem Sinne macht (740. 746. 748), pariert er rasch. Aber wenn Haimon nicht von seiner Liebe redet (kaum hätte die attische Klassik die Sprache dafür), wenn er sie nicht als Argument in den Streit einführt, so ist damit nicht gesagt, dass er sie nicht empfände”.), y por H. Erbse, éste último en un trabajo en manifiesta respuesta, ya que lleva el mismo título, "Haimons Liebe zu Antigone”, RhM 134, 1991, 253-61, aquí 259 ("Es ist jedoch schwerlich 
El Eros del que nos habla el coro en el estásimo de la Antígona no es otro que el que años después, reformulado y adecuado al contexto y, sobre todo, a sus intereses ${ }^{16}$, encontramos en Platón, ese Eros que mueve al ser humano hacia la belleza en todas sus manifestaciones posibles, hacia la creación, y también el que lleva a la recreación o, si se prefiere, a la procreación, una manifestación esta última de Eros que confluye con otras motivaciones en acciones tan señaladas como la toma y destrucción de Ecalia por Heracles o la de Troya por la expedición panhelénica, y que son sobradamente conocidas y temidas ${ }^{17}$. Esa manifestación del poder de Eros, que por su acusada visibilidad puede llegar a oscurecer otras motivaciones, era bien conocida por los griegos, y, naturalmente, en la tragedia de Sófocles la podemos encontrar, pero más que como aquello que mueve a la acción como reacción que tiende a reorientar o, en su caso, neutralizar los efectos de acciones motivadas por esa fuerza tan poderosa como es el Eros en su forma de pasión amorosa ${ }^{18}$. La toma de Ecalia por Heracles, como ya hemos dicho, es uno de esos hechos notables que cuenta entre sus motivaciones con esa manifestación del poder de Eros, y de sus consecuencias se sirve Sófocles para una de sus tragedias en las que nos saca a escena un personaje femenino no menos logrado que su Antígona y en otros aspectos tan original como ella, la Deyanira de Traquinias.

statthaft, diese ethischen Motive von der Liebe des Mannes zur Frau abzutrennen und lediglich ihnen dramatische Wirksamkeit zuzuerkennen.").

${ }^{16}$ Cf. V. Pirenne-Delforge, "Epithètes cultuelles et interpretation philosophique. A propos d'Afrodite Ourania et Pandemos à Athènes", AC 57, 1988, 142-57.

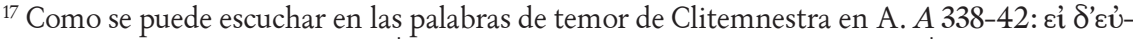

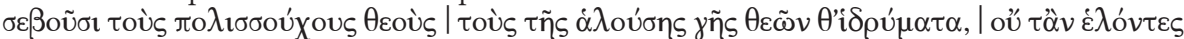

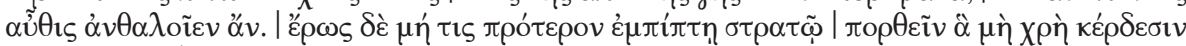

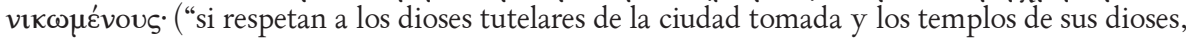
los conquistadores no serán a su vez conquistados. iQué no sobrevenga al principio al ejército un deseo de caer sobre lo que no deba, vencido por las ganancias!").

${ }^{18}$ En la creación de sus personajes Sófocles somete a las figuras míticas a un proceso de aproximación a la realidad social cuyos resultados son más perceptibles en los personajes femeninos en la medida en que el marco de acción que la sociedad les concede es más limitado $\mathrm{y}$, en consecuencia, está mejor definido, un proceso que consiste básicamente en despojarles de aquellos rasgos de carácter que puedan resultar inapropiados en una mujer; cf. J.V. Bañuls - P. Crespo, "La imposible Medea de Sófocles", en Fr. De Martino (ed.), Medea: Teatro e communicazione, Bari 2006, 23-66. Queda fuera, pues, de los presupuestos dramáticos de Sófocles el servirse de la pasión amorosa como motivación, aun cuando ésta pudiera ser esperable e incluso aceptable, al no constituir una amenaza para el ordenamiento político, presente siempre bajo el conflicto trágico que desarrollan sus dramas. Sobre la no dramatización de la pasión amorosa por parte de Sófocles, cf. J.V. Bañuls - P. Crespo, "Los no rechazables dones de la áurea Afrodita en Sófocles", en Cl. Benoit \& alii (eds.), Escrituras del amor y del erotismo, Valencia 2009, 39-51. En esta línea, una de las características de los dramas de sátiros de Sófocles es la ausencia en ellos de motivaciones vergonzosas, como señala M. Carmagnola, en "Qualque aspetto dell'arte satiresca di Sofocle nel confronto con Eschilo ed Euripide”, Dioniso 22, 1959, 205-13, lo que contrasta con el papel tan relevante que en ellos tenían los coros de sátiros, como señala Fr. Jouan, en "Sophocle et le drame satyrique", Pallas 37, 1991, 7-23, que lo considera una marca de arcaismo. 
Deyanira es la esposa legítima de Heracles al igual que Antígona es la prometida de Hemón, pero la acción de Deyanira no está motivada por la pulsión erótica hacia Heracles, sino por los más que probables efectos sobre el mundo de Deyanira del último de los objetos de la pulsión erótica de Heracles, un objeto que, naturalmente, tiene nombre, Yole ${ }^{19}$, y renombre, como la misma Deyanira indignada exclama en referencia a su nombre y a su cuna en los vv.

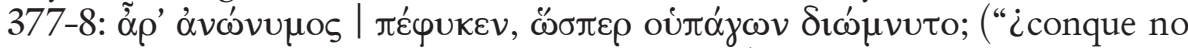
tenía nombre, como juraba el que la ha traído?"). La joven que trae Heracles consigo supone si no el desplazamiento de Deyanira de la posición que como mujer legítima tiene en el oikos, sí al menos un debilitamiento muy notable y a la vez progresivo de esa posición. Deyanira comprende a Heracles, conoce bien a su esposo, sabe de todas sus correrías, de sus aventuras, y comprende a todo aquel que es presa de la pasión erótica, conoce bien ese aspecto de la naturaleza humana que le confiere una gran labilidad (vv. 438ss.), sabe también, como alega Paris en $I l$.3.64-6, que los dones de la áurea Afrodita no son rechazables, y que esos dones pueden llegar a ser una verdadera ate, una ofuscación del entendimiento, como hemos oído referir al coro de Antígona en el estásimo segundo, como a su vez alega Helena en Od. 4.259-64. Deyanira sabe que quien se alza frente a Eros no está en su sano juicio, una divinidad a la que no escapan ni dioses ni hombres, por ello no puede reprochar a Heracles haber sido presa de esa enfermedad ${ }^{20}(\tau \tilde{n} \delta \varepsilon \tau \tilde{n}$ vó $\sigma \omega$, v. 445). Deyanira sabe y comprende todo eso, como deja bien claro con sus propias palabras, vv. 436-69, incluso comprende la situación de Yole, pues ella misma ha estado en situaciones similares, incluso peores ${ }^{21}$. Pero esa capacidad de comprensión de la que hace gala, propia de una mujer experimentada, en modo alguno anula su capacidad de reacción ante una amenaza como la que la joven Yole representa para ella, que ya no es joven. Reacción de Deyanira que es proyección en el plano humano de una reacción semejante en el plano divino, pues esta tragedia nos habla de la proyección de un conflicto desde el plano divino al humano para hallar en él solución definitiva, una solución realmente trágica

${ }^{19}$ En el caso citado de Agamenón también tiene nombre: Casandra. Pero con Casandra hay otras motivaciones que se explicitan: la propia sangre vertida, esto es, Ifigenia y con ella todo lo que hay tras la expedición contra Troya, muestra de la complejidad que hay detrás de las motivaciones humanas centradas en apariencia en la pulsión erótica.

${ }^{20}$ Aunque es en Eurípides donde la forma Eros-nósos alcanza un desarrollo mayor, ya es perceptible en Sófocles.

${ }^{21}$ Como señala muy acertadamente $\mathrm{M}^{\mathrm{a}}$ do C. Fialho, "Vivência e expressão de Eros em Sófocles, Traquínias: (Tradição e Novidade)", Humanitas 54, 2002, 49-62, aquí 56-7: "A compaixão por Íole e pelo destino suscitado pela sua beleza parecem deixar transparecer a projecção sobre Íole do própio destino e dos medos da juventude de Dejanira. (...) Do destino de Dejanira, vítima da particular violência de um impulso que domina o universo - o que a descrição da luta corpo a corpo, em que se mistura o homem e a besta, salienta expressivamentese desprende a indirecta identificação com o da jovem Íole, separada, como aquela, à força, da sua casa de origem". 
para los humanos: el affaire de Zeus con Alcmena, que provoca la reacción de Hera, adquiere en el plano humano la forma del affaire de Heracles con Yole, que provoca la reacción de Deyanira.

Los temores de Deyanira se revelan fundados cuando finalmente consigue saber la verdad sobre la joven cautiva. El coro, formado por jóvenes traquinias, que ha presenciado la escena, fuertemente impresionado, entona el estásimo primero, lleno de evocaciones a la gran lírica coral ${ }^{22}$, formado por un par estófico, vv. 497-506 507-16, seguido de un epodo, vv. 517-30, donde reafirma la fuerte impresión que ha recibido declarándose $\theta \alpha \tau \eta \rho^{23}$, "espectadora", v. 526:

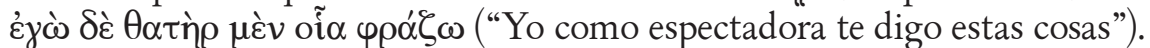

La estrofa canta el poder de Cipris; la antístrofa, por su parte, concreta ese poder en su manifestación erótica en la disputa de la que fue objeto Deyanira entre Arqueloo y Heracles, trabados en combate singular. Subrayan las jóvenes traquinias el poder invencible de Cipris, capaz de someter a los dioses más poderosos, lo que muestra nombrando a los tres dioses responsa-

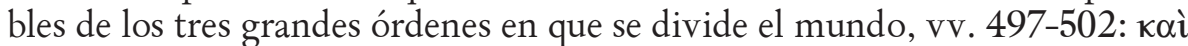

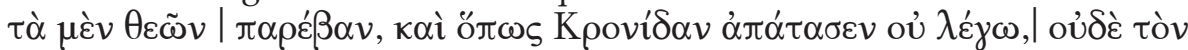

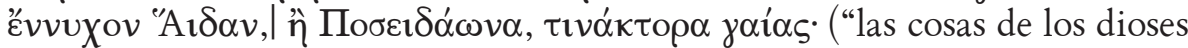
paso por alto, y no diré cómo engañó al Cronida, y al tenebroso Hades, o a Poseidón, el que hace temblar la tierra"), poder que se proyecta también a los

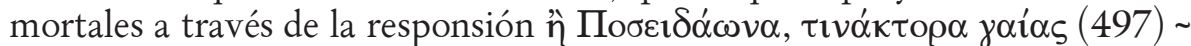

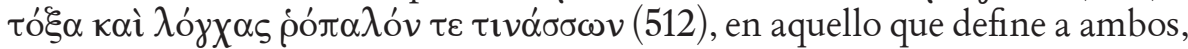

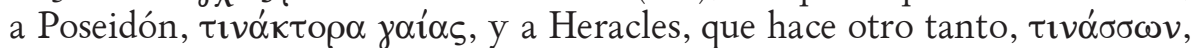
con arco, flechas y maza. Al referirse a Heracles en la antístrofa, lo hace subrayando su condición de $\pi \alpha$ ĩ $\Delta$ iós (v. 513), que en este contexto hace aflorar ese rasgo de carácter que comparten padre e hijo y en el que ambos sobresalen: sus frecuentes infidelidades conyugales ${ }^{24}$. Y también a través de la responsión nos habla de la forma que presenta en este caso ese poder y el

\footnotetext{
${ }^{22}$ Para este género de evocaciones remitimos a R. W. B. Burton, The Chorus in Sophocles' Tragedies, Oxford 1980, 54-5, y muy especialmente al estudio de Rodighiero ya citado (supra n. 3). También es muy sugerente R. Nicolai, "La crisi del paradigma: funzioni degli exempla mitici nei cori di Sofocle”, en A. Rodighiero \& P. Scattolin, “... un enorme individuo, dotato di polmoni soprannaturali”. Funzioni, interpretazioni e rinascite del coro drammatico greco, Verona 2011, 1-36, que en 14-9, considera que este estásimo amplifica el pathos mediante un parádeigma oikeíon en el que el coro se convierte en narrador de la historia de la protagonista, lo que es puesto en relación con los embólima de las tragedias tardías de Eurípides.

${ }^{23}$ La lectura $\theta \alpha \tau \eta \dot{\rho}$ fue propuesta por Th. Zielinski, "Excurse zu den Trachinierinnen",

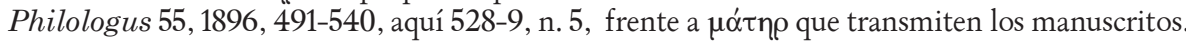
Como hace ver Rodighiero, La morte di Eracle (Trachinie), Venezia 2004, 183-4: "La lezione dei manoscritti risulta priva di senso nel contesto, e la prima obiezione è che il coro è composto da ragazze, ed è impossibile che le giovani si considerino madri di Deianira como pensare il parallelo di Elettra 233-34".

${ }^{24}$ Con relación a Zeus señala P.E. Easterling, Sophocles. Trachiniae, Cambridge 1982, 135: "Zeus was a notorious lover, and Poseidon too, though on a less grand scale; Hades was associated only with the rape of Persephone".
} 


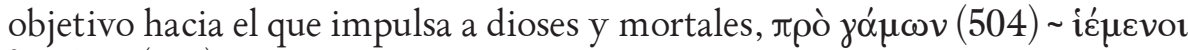
$\lambda \varepsilon \chi \varepsilon ́ \omega v(514)$.

Cierra el coro la antístrofa con los vv. 515-6, en los que recuerda que Cipris sola fue quien decidió la disputa entre Aqueloo y Heracles: $\mu$ óvo $\delta$ '

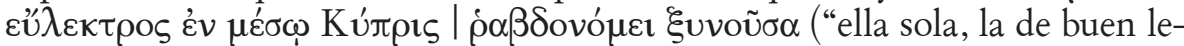
cho, Cipris, estando presente en medio, es árbitro del combate"). En esta imagen de Afrodita como juez que dirime una contienda, anticipa Sófocles esa Afrodita a la que al comienzo hacíamos referencia, que en Edipo en Colono, su tragedia postrera, recuperará en su función primera. En lo que en principio puede parecer una atribución a Cipris de un poder excesivo, reafirmada en los vv. 860-1, explicable por la juventud de las coreutas, se esconde una verdad más profunda, pues sólo Atenea, Ártemis y Hestia están a salvo del poder de Afrodita. Al cerrar de este modo la antístrofa cierra el par estrófico en una Ringkomposition con el v. $497^{25}$, que abre el canto, subrayando con

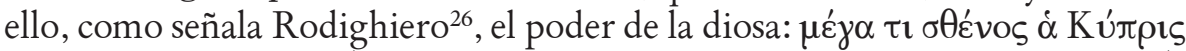

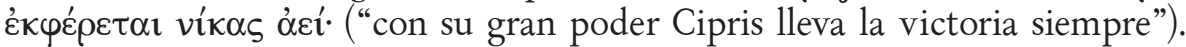
En sus manos, pues, estuvo el destino de Deyanira, aun cuando ella misma en el v. 26 afirmase la primacía de Zeus en la contienda, y ahora de nuevo vuelve a estarlo ${ }^{27}$. Al igual que el estásimo tercero de Antígona, también este canto está situado en un momento en el que se tiene conocimiento de un hecho que va a desencadenar una serie de desgracias que lo revestirá de trágico: allí, la llegada de Antígona, presa, camino de la que va a ser su cámara mortuaria; aquí, la de Yole. Y en ambos casos le siguen escenas que preludian nuevos males: en Antígona anuncios de actos funestos por parte de Hemón, en Traquinias la preparación de los presentes a Heracles, que causarán su muerte.

El coro canta el poder de Afrodita, el que sojuzgó años antes a Heracles, cuando luchó con el río Aqueloo, que también pretendía a Deyanira; ese mis-

${ }^{25}$ A. Cuny, Une leçon de vie. Les réflexions générales dans le théâtre de Sophocle, Paris 2007, 271-3, llama la atención sobre el comienzo de este canto, v. 497, con una máxima que pone el acento en ese tremendo poder de Cipris.

${ }^{26}$ Sofocle. La morte di Eracle (Trachinie), Venecia 2004, 183: "Nella struttura ad anello il motivo della potenza della divinità apre la strofe de lo estasimo e sigilla l'antistrofe".

${ }^{27}$ Se ha relacionado este estásimo con el fr. $941 \mathrm{R}$. inc. fab. de Sófocles, atribuido por Welcker a su Fedra y por Nauck a Dánae de Eurípides, y cuyas semejanzas con el fr. 684 R., más breve, transmitido por Estobeo como de su Fedra, son muy relevantes; cf. sobre la relación entre los dos fragmentos J.V. Bañuls \& P. Crespo, "La Fedra de Sófocles", en A. López \& A. Pociña (eds.), Fedras de ayer y de hoy. Teatro, poesía, narrativa y cine ante un mito clásico, Granada 2008, 15-83, en concreto 66-7. Para los problemas del fr. 941 R., cf. M.P. Pattoni, "Sofocle fr. 941 R.: testo e interpretazione", en G. Avezzù (ed.), Il drama Sofocleo. Testo, lingua, interpretazione, Stuttgart-Weimar 2003, 223-252. En nuestra opinión las diferencias son notables, aunque en ambos casos se canta el poder invencible de Afrodita: en Traquinias se trata de la utilización de una escena del pasado de Deyanira, que adopta la forma de exemplum mitológico, mientras que en este fragmento un personaje está intentando persuadir a otros más jóvenes de la inutilidad de luchar contra ese poder, sea para justificar algo ya hecho, sea para llevarles a una determinada decisión. 
mo poder es el que sigue dominando al héroe, a causa del cual ha destruido el reino de Yole y matado a todos los suyos. Este poder de Cipris es ratificado en el tercer estásimo, vv. 821-62, en el que se anticipa la conclusión a la que llegará Heracles proyectándose las desgracias sufridas por el héroe a un plano trascendente: el cumplimiento de un oráculo, para el que la divinidad se ha servido de los temores de Deyanira, unos temores causados por las consecuencias que para ella tiene la acción de Heracles y lo que le llevó a tal acción, a la toma y destrucción de Ecalia. Y todo ello en silencio gravita a lo largo de la obra inclinando la acción de los personajes hacia un destino anunciado que ahora va a aflorar con fuerza, como claramente cantan, en perfecta responsión con los dos versos finales de la estrofa, vv. 850-1, los versos finales del

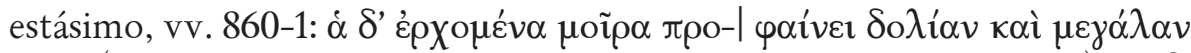
ó $\tau \alpha \nu$ ("El destino que se acerca anuncia una dolosa y gran desgracia") $\sim \dot{\alpha} \delta$ '

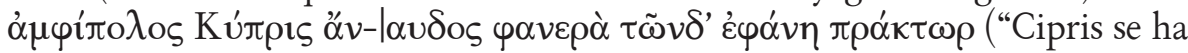
mostrado como evidente cumplidora, bien dispuesta y en silencio, de estos males"). Se establece a través de la responsión una relación de identidad entre

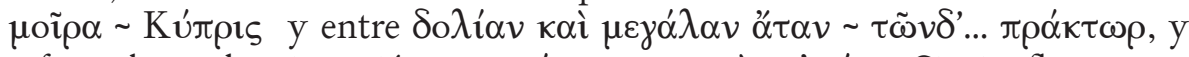

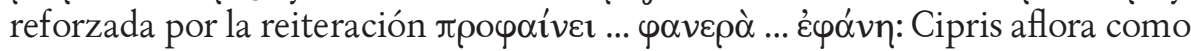
ejecutora última del destino fijado para Heracles, ella es la que, bien dispuesta y en silencio, ha movido los hilos de un destino, el de Heracles, que ha de cumplirse ${ }^{28}$, como él mismo, sabedor ya de la verdad, reconoce finalmente en

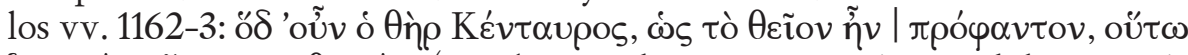

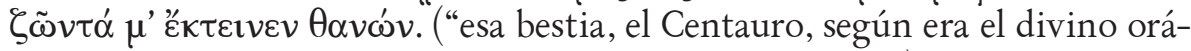
culo, así, a mí que estoy vivo me mata estando él muerto").

En dos tragedias de Sofocles de las consideradas tempranas, Antígona y Traquinias, hemos visto en gradación las diferentes formas en que puede hallar concreción Eros-Afrodita. A través de sus coros fundamentalmente nos habla Sófocles de un poder capaz de subyugar a hombres y a dioses, un poder que desdoblado en esa dualidad de Eros y Afrodita, subyace como motivación primigenia en todos los seres y en la propia naturaleza, y lo hace desarrollando esa dualidad, presentándonos las diferentes formas en las que halla expresión. Y así, desde el impulso general primigenio, muy presente en Antígona, en toda motivación humana, pasando por una primera concreción de ese impulso en forma de amor, parte sustancial de los lazos de philía, presente en los sentimientos de Hemón hacia su padre y hacia la que es su prometida, y en su concepción de la comunidad política griega que desarrolla en el agón con su padre, hasta la referencia a Afrodita a través de su gentilicio Cipris, en la que alcanza una de sus formas más concretas y visibles, el impulso erótico, en el Heracles de Traquinias, que motiva la

${ }^{28} \mathrm{El}$ conocimiento del oráculo pone de relieve la ineficacia trágica de los personajes, como indica E. R. Schwinge, Die Stellung der Trachinierinnen im Werk des Sophokles, Göttingen 1962, 102. 
reacción de Deyanira. Y en la que es su tragedia postrera, Edipo en Colono, Sófocles introduce de nuevo a Afrodita, y lo hace de una forma y en un sentido singulares. Se trata de un canto coral célebre ya en la Antigüedad y del que tenemos un precedente en otro canto coral de otro de los grandes trágicos, Eurípides, en concreto en su Medea, con notables puntos de contacto y no menos notables diferencias.

El pasaje de Medea es entonado por el coro poco después de concluir la conversación entre Egeo y Medea, asegurándole éste bajo juramento, pues así se lo ha exigido ella, asilo seguro en Atenas, vv. 708-58. Cuando concluye la conversación entre Egeo y Medea, después de un breve e infructuoso intento del coro por hacerla desistir del modo en que se propone responder a la traición de Jasón, entona el coro este estásimo que se abre con un primer par estrófico en el que hace una alabanza de Atenas y de los atenienses.

En este primer par estrofico se establece a través de la responsión una relación entre los Erecteidas ${ }^{29}$, los atenienses, y el Céfiso, río que siempre fluye, que siempre lleva agua, divinidad del Ática, que al igual que el flujo humano de los atenienses, desde antiguo afortunados en extremo y de de-

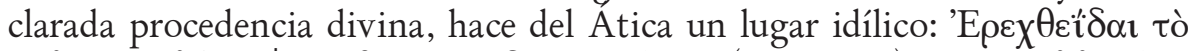

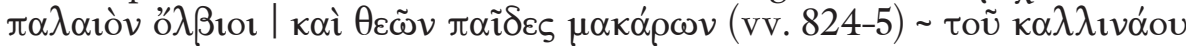

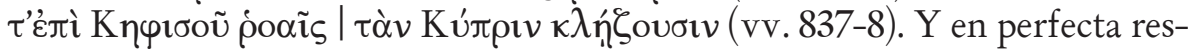
ponsión, vv. $826 \sim 839$, encontramos la tierra, $\chi \omega \dot{\rho} \rho \alpha \varsigma \sim \chi \omega \dot{\rho} \rho \alpha \nu$, la tierra del Ática, de donde proceden los atenienses, la misma tierra que les nutre, que les confiere la más ilustre sabiduría, una tierra por la que Afrodita esparce dulces brisas que hacen del Ática el habitat idóneo al que se atribuyen las cualidades $\mathrm{y}$ virtudes de los atenienses, $\mathrm{y}$ ambas expresiones se encuentran en respon-

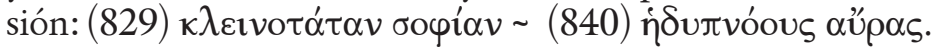

A través de la responsión entre los versos finales de la estrofa (832-5) y de

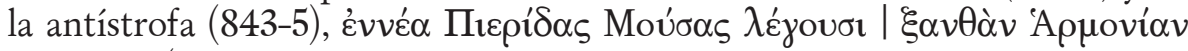

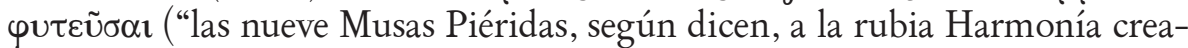

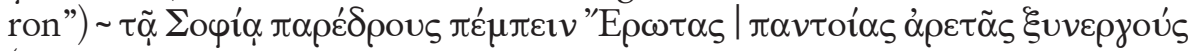
("envía a los Amores como compañeros de la Sabiduría, colaboradores de todo tipo de virtudes"), se subraya la vinculación de la rubia Harmonía a las nueve Musas, símbolo de la unión armónica de las diferentes artes y saberes en la tierra ática, lo que se ve desarrollado en la antístrofa por los impulsos de Eros, que, asociados a Sophía, unen sus esfuerzos en la consecución de todo género de aretés. Y todo ello es presentado como permanente y constante, lo que se pone de manifiesto por la responsión de aizì, tan permanente y cons-

${ }^{29}$ En el doblete Erictonio-Erecteo, como ya ha señalado N. Loraux en Les Enfants d'Athéna. Idées athéniennes sur la citoyenneté et la division des sexes, Paris 1981, 47, no hay que ver necesariamente una dualidad de personas, sino más bien un proceso, esto es, uno, Erictonio, funda aquello cuya permanencia asegura el otro, Erecteo, o incluso a la misma persona pero en dos etapas de su vida diferentes, de niño y de adulto. 
tante como lo vienen siendo los atenienses en las tierras del Ática, de las que se declaran autóctonos ${ }^{30}$.

Uno de los objetivos que persigue el coro al entonar este primer par estrófico se ve con bastante claridad cuando entona el segundo par, en el que ya abiertamente se plantea el contraste y la falta de armonía entre la idílica tierra ática cantada y la acción que se propone llevar a cabo Medea ${ }^{31}$ : se trata de un intento desesperado por hacer desistir a Medea de la decisión que ha tomado. $\mathrm{Y}$ a los espectadores, y en particular a sus dirigentes, un llamamiento a la prudencia en la toma de decisiones y en la adquisición de compromisos ${ }^{32}$ en unos momentos en los que los atenienses iniciaban una andadura no carente de riesgos, como los años demostraron sobradamente; y lo hace Eurípides desde una posición distante e incluso arriesgada: la atribución de la autoría de la muerte de los niños a Medea supone por parte de Eurípides la adopción de una posición conciliadora en unos momentos de una gran tensión ${ }^{33}$. Al

${ }^{30}$ Se recoge aquí uno de los motivos típicos de la propaganda ateniense, la condición de autóctonos; cf. N. Loraux, L’invention d'Athènes, Paris 1993, y M. Valdés, El nacimiento de la autoctonía ateniense: cultos, mitos cívicos y sociedad de la Atenas del s.VI a.C., Madrid 2008.

${ }^{31}$ No es gratuita la insistencia del coro en la sophía, dada la importancia que tiene en la configuración del complejo personaje de Medea, como ha sido señalado, entre otros, por J. Assaël, Euripide, philosophe et poète tragique, Louvain 2001, 217-27. Esa insistencia refuerza la integración del canto en el conjunto de la tragedia, pues detrás de la historia de Jasón, en su conjunto, subyace un sentimiento muy arraigado de temor hacia lo "otro" y hacia lo "desconocido", hacia lo que hay más allá de los límites impuestos al ser humano, unos límites que Jasón transgrede con aparente éxito sirviéndose de una persona del más allá, de Medea, no griega y poseedora de una sophía extraña al mundo griego.

${ }^{32}$ Hoy es una opinión generalmente aceptada que Eurípides presentó ante los atenienses su Medea cuando éstos ya habían asistido a la representación de su Egeo, donde dramatizó los problemas y sinsabores que a Egeo le acarreó el compromiso adquirido con Medea.

${ }^{33}$ La primera referencia a la muerte de los hijos de Medea y Jasón la encontramos en Creófilo de Samos, que nos informa de que Medea ya en Corinto dio muerte a Creonte, tras lo cual, por temor, marchó a Atenas dejando en Corinto, en el templo de Hera, a sus hijos en la esperanza de que el lugar sería respetado y de que su padre Jasón se haría cargo de ellos. Pero los corintios, encolerizados por la muerte de Creonte, no respetaron el templo y les dieron muerte, difundiendo después la calumnia de que había sido obra de Medea. A esta calumnia hace alusión Pi. $O$. 13.47-54; y aunque en este epinicio canta las proezas de un corintio, presenta a Medea bajo una luz favorable. Pero con independencia de que sea o no una calumnia, la información de Creófilo supone la existencia de dos versiones de este asunto, y Eurípides se habría limitado a optar por una de ellas. Pero al hacerlo estaría dando por cierta la versión de los corintios, o en palabras de L. Séchan, Études sur la tragédie grecque dans ses Rapports avec la céramique, Paris 1926, 58: "Euripide n'aurait fait que l'accueillir et apporter une adhésion éclatante à l'une des thèses en présence dans un débat ouvert depuis longtemps". También se apunta un hipotético precedente, el de Neofrón y su Medea, cuestión polémica, pero que nada aporta a lo que aquí nos interesa. Sí puede ser relevante en cambio, con independencia de que sea cierto o falso, lo que Parmenisco señala, según recoge el escolio al v. 10 de Medea, que Eurípides recibió de los corintios cinco talentos para hacer recaer sobre Medea la autoría de la muerte de sus hijos, pues nos estaría hablando de la impronta que dejó la reacción provocada por la obra en buena parte de los espectadores. 
considerar esta tragedia no debemos perder de vista que el ambiente en el que Eurípides la compone y la lleva al teatro está mediatizado por los conflictos entre los atenienses y los corintios, y que hasta el último momento los atenienses no se mostraron decididos a ir a la guerra, al menos esa es la impresión general que de todos estos acontecimientos deja el relato de Tucídides ${ }^{34}$. Sin duda, pues, habría, entre los atenienses posturas diversas ante unos hechos tan preocupantes como los que se estaban desarrollando ${ }^{35}$.

Diferente pero no menos preocupante era la situación de los atenienses cuando Sófocles compuso su Edipo en Colono, y encontrados y confusos los sentimientos de éstos cuando, ya muerto el poeta, fue representada en una Atenas por completo vencida. Dos situaciones distantes, pero no tan diferentes, al menos en lo que hace a la gravedad y trascendencia: la de aquella Atenas que se estaba embarcando en una guerra incierta, $y$ esa Atenas que ha de tomar consciencia de la realidad $y$, finalmente, afrontar las consecuencias de aquella guerra.

El estásimo primero de Edipo en Colono está considerado uno de los cantos a Atenas más bellos, ensalzada en un momento en que se vislumbraba el final por parte de un Sófocles ya anciano, un estásimo éste que deja traslucir a la par que el gran amor de Sófocles por su polis, los temores y presentimientos de lo que finalmente iba a ocurrir ${ }^{36}$. Este pasaje de Edipo en Colono es ento-

${ }^{34}$ Corinto juega un papel importante en los orígenes de la guerra, así, el asunto de Corcira, en el 433 , el de Potidea, en el 432, en todos de un modo u otro están implicados atenienses y corintios. Estos enfrentamientos indirectos y, sobre todo, las negociaciones que desde el 433 hasta la ruptura del 431 se llevaron a cabo nos muestran una situación en la que la paz o la guerra eran opciones posibles, y como tales tendrían partidarios. En las negociaciones en torno al problema de Corcira entre atenienses y corintios los argumentos de estos últimos debían gozar de cierto crédito, ya que los atenienses no establecen una alianza plena $\left(\sigma v \mu \mu \alpha \chi^{i} \alpha\right)$ con los cor-

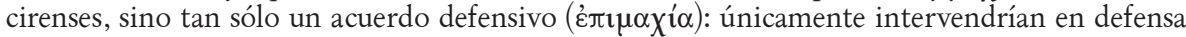
de los corcirenses si éstos eran atacados por los corintios (Th. 1.44.1). Otro tanto cabe decir de los corintios, ya que un año después, cuando estalla el conflicto de Potidea en el verano del 432 , para evitar una implicación directa, no envían un contingente regular, sino mercenarios peloponesios reclutados y únicamente un cuerpo reducido de voluntarios (Th. 1.60.1).

${ }^{35}$ Compartía con Medea lugar en la tetralogía Filoctetes, del que tenemos noticia a través de dos piezas oratorias de Dión Crisóstomo, la 52, en la que compara los tres Filoctetes, y la 59, en la que lleva a cabo una paráfrasis del comienzo del Filoctetes de Eurípides. Y no debe de ser ajeno al contexto en el que Eurípides compone su obra, el hecho de que una de las mayores novedades introducida en su Filoctetes sea la presencia de una embajada troyana encabezada por Paris, y de que, como nos informa Dión en 52.14, los coros de Eurípides abundasen en exhortaciones a la virtud, y en 52.11, que la tragedia tenía un sentido más político y una notable presencia de discursos: $\pi$ o de Esquilo como en el de Eurípides, Filoctetes finalmente, después de reconsiderar su postura, cambia de opinión y se embarca rumbo a Troya para reintegrarse a la expedición.

${ }^{36}$ Como señaló Lesky, La tragedia griega, 245: “También Sófocles, cuya felicidad llegó a ser proverbial para los atenienses, experimentó lo caduco de la dicha, y muchas de las cosas que alegraron su vida se convirtieron en nada. Pero una cosa llevó consigo hasta los últimos días, así como la fuerza de su obra creadora: el amor a Atenas, antes de cuya caída habría de cerrar los ojos para siempre. Sin embargo, tuvo el presentimiento de que esta caída habría de producirse. Así, en la Atenas de su drama, en Teseo sobre todo, hace surgir una vez más la imagen de su pura 
nado por el coro cuando Teseo se marcha, acabada la conversación con Edipo, en la que le garantiza protección y seguridad en las tierras del Ática; pero hay aquí ya un dato que muestra la diferencia entre el planteamiento de Sófocles y el de Eurípides en su Medea: a Teseo no le exige Edipo juramento, lo que es subrayado de forma explícita; a Egeo, en cambio, Medea le exige que selle con un juramento su compromiso, lo que causa sorpresa y extrañeza a Egeo. Pero Medea no es Edipo, ni Eurípides pretende proyectar nada semejante a lo que proyectará a través de su obra Sófocles desde su Antígona. Aquellas palabras del coro en Antígona, a las que ya nos referimos, no exentas de ironía trágica, los vv. 471-2, premisa velada de un proceso allí iniciado, la positivación del héroe trágico en la figura de su Edipo desarrollado en Edipo Rey, alcanza su telos en Edipo en Colono, con el establecimiento de un punto de contacto entre el plano humano y el divino ${ }^{37}$ en la persona de Edipo.

El inicio del estásimo primero, vv. 668-719, así como también el del segundo, vv. 1044-95, está marcado por la marcha de Teseo, dos estásimos perfectamente integrados en el contexto trágico tanto por el contenido como por su secuenciación dramática: el primero proyecta un cuadro fruto de imágenes convergentes de dos pasados, remoto el uno, no tan remoto el otro ${ }^{38}$, pero ambos presentes en el imaginario de los atenienses, una convergencia que guarda no poca semejanza con aquella de la que es fruto la tragedia griega, en la que detrás de la saga mítica que sirve de materia a la obra, late con fuerza una realidad no tan lejana ${ }^{39}$, pero todo ello con el distanciamiento ${ }^{40}$ suficiente

grandeza, y en el primer canto de la obra (vv. 668ss.), en uno de los más bellos de la literatura griega, alaba el hechizo de su patria, protegida por los dioses".

${ }^{37}$ Precisamente en este sentido es interesante la analogía que establece entre el mundo que proyecta la obra de Hesíodo y el destino de Edipo E. Masaracchia, en "Motivi esiodei nell'Edipo a Colono", Dioniso 51, 1980, 81-95, aquí 85-6 y 94-5: "Edipo diventerà il benefico custode e protettore dell'Attica, con una concezione che sembra derivare da quella esiodea degli uomini

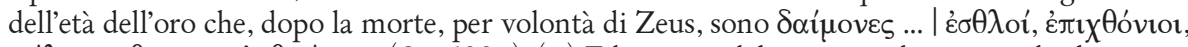
$\varphi \dot{\lambda} \lambda \alpha \kappa \varepsilon \varsigma \theta \nu \eta \tau \tilde{\omega} v \dot{\alpha} \nu \theta \rho \omega \dot{\pi} \pi \omega v($ Op. 122s.). (...) Edipo esce dal suo precedente mondo, le cui caratteristiche sono invece quelle dell'età del ferro (figli che maltrattano i padri, fratelli in lotta fra loro), per diventare membro della città giusta e assumere, dopo la sua morte, la funzione di demone, attingendo e fondendo in sé i due aspetti dei $\delta \alpha i \mu o v \varepsilon \varsigma$ esiodei, quello di protettori degli uomini e quello di custodi della legge morale voluta dagli dèi”.

${ }^{38}$ A ese pasado no tan remoto se está refiriendo M. Blundell, "The ideal of Athens in Oedipus at Colonus", en A. H. Sommerstein \& alli (eds.), Tragedy, Comedy and the Polis, Bari 1993, 287-306, cuando señala que la Atenas representada en esta tragedia procede del ideal pericleo. Pero más bien habría que decir que se trata de una polis ideal, como subraya A. Rodighiero, Sofocle. Edipo a Colono, Venezia 1998, 201, "sospesa tra realtà e finzione, tra geografia e letteratura", lo que le confiere una potencialidad superior a la mera realidad objetiva.

${ }^{39}$ Como indica G. Guidorizzi en Edipo a Colono. Sofocle, introd. e commento G. Guidorizzi, testo critico G. Avezzù, trad. G. Cerri, Milano 2011 (=2008²), XVII.

${ }^{40}$ Un distanciamiento no tan extremo, como el que, en nuestra opinión, plantea V. Di Benedetto, Sophocle, Firenze 1983, 231 y 234: "il modulo propagandistico pericleo appare nella tragedia svuotato di un valore autentico; e ad esso si sovrappone un ordine di idee diverso: entro questo ordine di idee, da una parte si recupera un modello culturale ben più antico, quello 
para que el cuadro que proyecta pueda tener el efecto buscado. En este estásimo, como señala $M^{a}$ do C. Fialho ${ }^{41}$, "A presença da dimensão sagrada da pólis é nítida, na celebração da plenitude do seu cosmos”. En el segundo estásimo ese pasado toma forma real en el presente a través de imágenes concretas de acción efectiva encabezada por Teseo en "un fragmento dramático"

La descripción breve que a instancias de su padre hace Antígona del lugar al que han llegado (vv. 16-20), completada por las palabras del coloniata a Edipo (vv. 53-63), preludian este estásimo: referencias al ruiseñor, al bosque, a sus flores y plantas, a lo sagrado del lugar y a los dioses protectores. En un estilo lírico muy marcado que evoca la gran tradición literaria anterior, en especial la lírica coral ${ }^{43}$, en el que no faltan ecos de las composiciones euripideas. De modo similar a lo que busca el coro de Medea, que aduce las bondades de Atenas para hacer cambiar de opinión a la protagonista, en el estásimo de Edipo en Colono el coro utiliza la alabanza a Atenas para reforzar la decisión de Edipo de quedarse en Atenas y ser su benefactor ${ }^{44}$.

El primer par estrófico focaliza el canto en Colono, desde donde irradia en el segundo a toda el Ática, materializando en esta secuenciación su condición de eje vertebrador de una realidad dispersa, una vertebración que se materializa haciéndose realidad en una acción efectiva en el estásimo segundo.

En clara responsión con la referencia a Dioniso y las Bacantes ${ }^{45}$, que encontramos en los vv. 678-80 que cierran la estrofa, en los versos finales de la antístrofa, vv. 691-3, junto al coro de las Musas se menciona a Afrodita: ǐv'ó

per cui il morto (l'eroe) dalla sua tomba può proteggere un territorio e una comunità, e d'altra parte la polis appare mossa nel suo intimo da considerazioni utilitaristiche che ben poco spazio lasciano all'affermazione di valori ideali. (...) In questo ordine di idee si colloca anche il famoso primo stasimo con la celeberrima lode dell'Attica. Non si può certo vedere in questo stasimo il segno di un'adesione di Sofocle ai valori più propriamente politici dello stato ateniese: ciò che Sofocle esalta non è la polis in quanto centro urbano, ma la campagna dell'Attica".

41 "Édipo em Colono: o testamento poético de Sófocles", Humanitas 48, 1996, 29-60, aquí 47. 131.

${ }^{42}$ Como subraya muy acertadamente Errandonea, Sófocles y la personalidad de sus coros,

${ }^{43}$ Cf. G. Cerri, "Nuovi generi corali nell' Edipo a Colono di Sofocle", en Fr. Perusino \& M. Colantonio (ed.), Dalla lirica corale alla poesia drammatica. Forme e funzioni del canto corale nella tragedia e nella commedia greca, Pisa 2007, 159-81, aquí 164-7.

${ }^{44}$ Burton, The Chorus in Sophocles, 274ss., pone de relieve la importancia de que sean ancianos los coreutas, lo que confiere mayor emotividad al canto contribuyendo a crear una atmósfera cercana a la plegaria. Este recurso entra también en juego en Medea, cuyo coro está formado por mujeres. En ambos casos se trata de personas del lugar, de edad similar a la de los protagonistas, lo que posibilita una comprensión mayor a la par que una relación más fluida.

${ }^{45}$ Aunque no hay testimonios seguros de la celebración de fiestas dionisíacas en Colono, la iconografía de los vasos lenaicos muestra escenas de danzas estáticas femeninas ante Dioniso, que debían practicarse en los demos rurales, incluido Colono. Para estas representaciones vasculares cf. Fr. Frontisi-Ducroux, Le dieu-masqué. Une figure du Dionysos d'Athènes, Paris 1991, y M.-C. Villanueva Puig, Ménades. Recherches sur la genèse iconographique du thiase fémenin de Dionysos, Paris 2009, 198ss. 


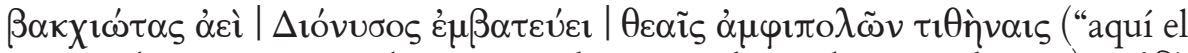
siempre bacante Dioniso bate su pie al servicio de sus diosas nodrizas") oủdè

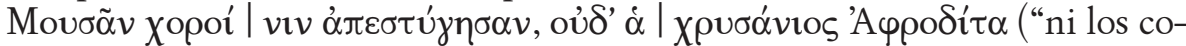
ros de las Musas la miran mal, ni tampoco la de las riendas de oro, Afrodita"). Encontramos aquí, como en otros lugares ${ }^{46}$ y vimos ya en Medea, una referencia a las Musas y a Afrodita juntas. La presencia de Afrodita aquí no ha extrañado por la estrecha relación que desde el principio tuvo esta diosa con la vegetación, y, por derivación, con los jardines ${ }^{47}$. Pero esta Afrodita no lleva aquí un epíteto relacionado con ese ámbito de actuación, sino el

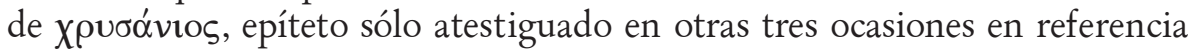
siempre a unas riendas áureas ${ }^{48}$, y sabido es que Afrodita conducía carros ${ }^{49}$, lo que lleva a Jebb finalmente a comentar que: "So, here, the epith. suggests a visit of the goddess from above" 50 . Comentario sugerente que debe ponerse en relación con el hecho de que Sófocles se sirva de un término de uso escaso y tono arcaico, lo que, en nuestra opinión, es acorde con la visión de Atenas que nos transmite el canto coral, aquella Atenas que sentó las bases de su grandeza posterior, una grandeza que alcanzó su cima en aquella otra Atenas anterior a la guerra, ya sin duda idealizada. En aquella Atenas, fruto en gran medida del imaginario colectivo ateniense, Afrodita era también una diosa protectora, con características de diosa guerrera, como se observa en otros lugares, y cuya fundación del culto se atribuía al padre de Teseo, a Egeo ${ }^{51}$. Pero fue progre-

${ }^{46}$ Basta recordar el proemio de Teogonía, a cuya evocación en el himno a Eros de Antígona ya nos hemos referido.

${ }^{47}$ En su comentario a Edipo en Colono señala Guidorizzi que "Secondo lo scoliasta, Afrodite aveva un altare presso l'Accademia" (288). Y Pausanias, aunque no menciona a Afrodita entre las divinidades objeto de culto en aquel lugar, habla de un altar a Eros (1.30.1): Afrodita era objeto de culto junto a Eros en la ladera norte de la Acrópolis, donde era conocido también como Afrodita "en los jardines" ( $\dot{\varepsilon} v$ kń $\pi 01 \varsigma)$.

${ }^{48} \mathrm{Il}$. 6.205, referido a Ártemis; Od. 8.285, a Ares; Pi. fr. 18 Bowra, en referencia a Hades.

${ }^{49}$ Sapph. fr. 1 Voigt, y Hor. Carm. 3.28.15.

${ }^{50}$ R. Jebb, Sophocles II. The Oedipus Coloneus, Cambridge 1907, 117. La observación de J. I. Armstrong, "The Arming-motif in the Iliad", AJPh 79, 1958, 336-54, en el sentido de que en la Ilíada Afrodita no desciende, como hacen las otras divinidades, en un carro tirado por caballos, subraya la limitación de sus funciones en este poema épico.

${ }^{51} \mathrm{La}$ tradición griega recogida por Pausanias relaciona a Egeo y Teseo con la instauración del culto a Afrodita en Atenas: sobre la instauración del culto a Afrodita Pandemos en el marco del proceso de sinecismo ateniense, Paus. 1.22.3, y sobre la instauración del culto a Afrodita Urania por Egeo, Paus. 1.14.7. En general, sobre Afrodita cf. el ya clásico trabajo de V. Pirenne-Delforge, L'Aphrodite grecque, Athènes-Liège, 1994, que subraya esa misma distinción, señalada por Pausanias: "Deux légendes de fondation sont attachées au sanctuaire d'Aphrodite Pandémos; Thésée, d'une part, aurait fondé le culte à l'issue du synécisme de l'Attique, la déesse devenant Pandémos parce que le héros avait réuni tout le peuple en une cité; Solon, d'autre part, aurait établi des esclaves féminines dans des maisons closes pour assouvir les besoins de la jeunesse athénienne et, avec l'argent amassé par les tenancières de ces établissements de prostitution, aurait instauré le culte d'Aphrodite Pandémos" (28). Posiblemente haya que ver aquí la asimilación en la tradición vinculada a Teseo de las medidas adoptadas por Solón, 
sivamente cediendo su puesto en este aspecto en beneficio de Atenea ${ }^{52}$, tan vinculada en el imaginario griego a Erecteo y con él al mito de la autoctonía ateniense, tan presente en el canto de Medea como ausente en el de Edipo en Colono $^{53}$. Esta recuperación del papel protector de Afrodita está en la misma línea que la recuperación del papel de aquellos héroes de viejo cuño simbolizados en el guerrero que da nombre a su Ayante, y ahora, en los tiempos difíciles que afronta Atenas, simbolizados en la figura de Filoctetes, y renovados y proyectados hacia el futuro en la del hijo de Aquiles, Neoptólemo.

En el canto, pues, culmina la manifestación de una de las características de esta obra, que, como la otra tragedia más cercana cronológicamente, Filoctetes, es un canto a la integración en la búsqueda necesaria de la armonía perdida.

Como ya señalamos al comienzo, en la fase final de la producción de Sófocles se puede observar un replanteamiento de sus posiciones anteriores, algo especialmente perceptible en el Filoctetes y, finalmente, en Edipo en Colono, que se traduce en una reformulación del conflicto trágico desarrollado en obras anteriores y en la forma en que éste se dramatiza, lo que es especialmente visible en la relación de su tragedia con los dioses y también en la reconfiguración e integración de sus personajes en la acción dramática, en Filoctetes, y en el establecimiento de un punto de contacto entre el plano humano y el divino centrado en la persona de Edipo en Edipo en Colono.

Las armas de Aquiles, cuya pública adjudicación a Odiseo motivó la cólera de Ayante en la tragedia homónima, en el Filoctetes ${ }^{54}$ se restituyen a su

entre ellas el establecimiento del culto a Afrodita Pandemos por Teseo en el marco del sinecismo y el establecimiento de la unidad de todo el pueblo que Solón sanciona con la inaguración del culto de Afrodita Pandemos; cf. M. Valdés, La reorganización religiosa en la Atenas del s. VI a.C., Madrid 1998. Sobre la ubicación de Afrodita en el friso del Partenón, cf. O. Palagia, The Pediment of the Parthenon, Leiden, $1998\left(=1993^{2}\right)$, en concreto el cap. $1^{\circ}$, "The East Pediment”, 18-39. La relación de Ártemis Brauronia y Afrodita en el friso este del Partenón ya fue señalada por E. Simon en Die Götter der Griechen, München 1969, 178.

${ }^{52}$ Como señala M. Valdés, "Los espacios de Afrodita en la polis arcaica de Atenas", Arys 5, 2002,3-30, aquí 6-7 y 18: "la diosa Afrodita estuvo en época arcaica, especialmente en el primer arcaísmo, estrechamente asociada a los principales cultos cívicos y vinculada con un papel similar y a la vez complementario, a la diosa Atenea de la Acrópolis. (...) El culto del bastión (...) se identificará en época oscura y el primer arcaísmo con la diosa Afrodita y permanecería asociada a esta diosa en su vertiente guerrera, típica de otros lugares de Grecia"; y de la misma, El papel de Afrodita en el arcaísmo griego. Política, guerra, matrimonio e iniciación, Messina 2005. La relación de Afrodita con la esfera de la guerra no es excluyente, sino complementaria, como subraya G. Pironti, "Aphrodite dans le domaine d'Ares. Éléments pour un dialogue entre mythe et culte", Kernos 18, 2005, 167-85.

${ }^{53}$ Como indica Di Benedetto, Sophocle, 236-7: "L'accenno alle Muse e ad Afrodite ricorda naturalmente il celebre pezzo del terzo stasimo della Medea di Euripide: ma dei «felice Eretteidi» di cui parlava Euripide non c'è in questo stasimo dell'Edipo a Colono nessuna menzione". Cf. también Burton, The Chorus in Sophocles, 279-80.

${ }^{54} \mathrm{El}$ mito de Filoctetes, del que nos ofrece una panorámica completa J. Lasso de la Vega en "El mito de Filoctetes", Sófocles, Madrid 2003, 157-85, fue objeto de tratamientos diversos antes de que los tres grandes trágicos se sirvieran de él para componer una tragedia; de ello G. 
primer dueño en la figura de su hijo, Neoptólemo; con ello Sófocles da testimonio de un cambio en la percepción de la realidad que se traduce en un replanteamiento del conflicto trágico desarrollado en la que probablemente sea la más antigua de sus tragedias conservadas, en su Ayante. Pero en los años en los que Sófocles lleva a escena su Filoctetes, en los años en los que compuso su Edipo en Colono, nadie sobra, todos son necesarios, incluso aquel Odiseo de su Ayante, proyección a la escena de los atenienses de aquellos tiempos gloriosos, ahora, transformado por los años y la interminable guerra ${ }^{55}$, al igual que, sin duda, lo estaban también los atenienses. Se plantea, pues, la necesaria aceptación e integración efectiva de aquellos héroes de viejo cuño, en el pasado simbolizados en el guerrero ${ }^{56}$ que da nombre a su Ayante, y ahora, en el presente, simbolizados en la figura de Filoctetes y en su proyección hacia el futuro en la del joven Neoptólemo ${ }^{57}$. Pero este replanteamiento va más allá, lo que se hace patente en una más abierta y directa apelación al plano divino, cuya presencia es notoria en ambas tragedias.

En el Filoctetes no son los argumentos los que hacen cambiar de opinión a los Atridas, como acontecía en el Ayante, sino la expresión de la voluntad de los dioses puesta en boca de los hombres, del mismo modo que ahora, en Lemnos, va a ser la intervención directa de un dios, Heracles, en origen un héroe mortal, la que va a hacer cambiar de opinión a Filoctetes, no los argumentos de Odiseo. La acción de Atenea en Ayante visualizaba, teatralizaba, la sanción divina de la decisión que los expedicionarios habían tomado sobre la asignación de las armas de Aquiles a Odiseo, una decisión que se ajustaba

Avezzù en Il ferimento e il rito. La storia di Filottete sulla scena attica, Bari 1988, nos ofrece una relación detallada. J. R. Ferreira, O drama de Filoctetes, Coimbra 1989, nos ofrece una excelente comparación entre el Filoctetes de Sófocles y los de Esquilo y Eurípides, especial en 9-14, "O mito de Filoctetes e inovações de Sófocles", y en 15-32, "Analise das figuras".

${ }^{55}$ Como señala Ferreira, $O$ drama de Filoctetes, 61: "un chefe militar que a guerra insensibilizou e libertou de todas as teias e pruridos marais", lo que es comprensible y no censurable después de tantos años de guerra.

${ }^{56}$ En los campos de Troya Ayante, en la tragedia homónima, se enfrenta a sí mismo, a ese Ayante que los demás perciben y proyectan sobre él, un Ayante que el propio Ayante no ve y, en consecuencia, no acepta. Y de ahí surge el conflicto trágico, de esa doble percepción. A Ayante le mueve su timé, la percepción que él tiene de sí mismo y, en consecuencia, de su timé, le mueve la ofensa de que se siente objeto en la asignación de las armas de Aquiles, ofensa para él, pero reconocimiento para Odiseo, como si con las armas de Aquiles, el gran heroe de la Ilíada, se pasara el testigo, se diera testimonio de que el mundo ha cambiado. En principio, la posición de Ayante puede parecer correcta, pues se ajusta a la moral heroica, pero en ella subyace aquel talante expuesto por el mensajero en los vv. 762-77, aquellas palabras con las que replicara a los prudentes consejos de su padre, y más tarde, ya en Troya, las que dirigiera a Atenea rechazando su ayuda, palabras unas y otras con las que mostró, como concluye el v. 777, que su pensamiento no se ajustaba a lo humano (oủ $\kappa \alpha \tau^{\prime}$ öv $\theta \rho \omega \pi \mathrm{ov} \varphi \rho o v \tilde{\omega} v$ ), con lo que se atrajo la ira divina, en particular la de Atenea.

${ }^{57}$ Cf. J.V. Bañuls - P. Crespo, "El Filoctetes de Sófocles, una propuesta regeneracionista", en Fr. De Martino \& C. Morenilla (eds.), El teatro greco-latino y su recepción en la tradición occidental, Bari 2006, 59-81. 
al orden recto de las cosas, por el que la divinidad vela. Pero aquella era una presencia divina diferente a la que se da en el Filoctetes de Sófocles, en la que podría haber sido Atenea la que hubiera aparecido ratificando ante Filoctetes y ante todos las palabras y la autoridad de Odiseo, una autoridad que le viene por el hecho de ser portador de la voluntad divina. Pero no es Atenea, sino Heracles, lo que es aún más notorio si se tiene en cuenta que en el Filoctetes de Eurípides era Atenea la que facilitaba la empresa a Odiseo. Con ello Sófocles abre el camino para la recuperación de aquella Afrodita protectora y para el establecimiento de un punto de contacto entre el plano humano y el divino centrado en la persona de Edipo en Edipo en Colono.

De modo similar a como sucede en Filoctetes, en Edipo en Colono también es la expresión de la voluntad de los dioses la que finalmente da salida a la situación. Pero en Edipo en Colono aún va más allá: plantea la integración de un héroe trágico en lo que es el punto final de un proceso apuntado en su Antígona, como ya señalamos, planteado y dramatizado en forma trágica en su Edipo Rey, pero no cerrado, pues en Tebas quedó Edipo aguardando su destino final (OT, vv. 1517-20), un destino en el que hombres y dioses deben converger, como ahora canta el coro en Edipo en Colono. En esta tragedia Sófocles pone ante los ojos de los espectadores a un Edipo que finalmente es aceptado por los dioses y, en consecuencia, debe serlo también por los hombres. Subraya con ello Sófocles que por muy grandes que hayan sido los errores cometidos por los hombres, una vez han sufrido y tomado consciencia, se abre ante ellos un camino de esperanza y de paz. Es, por tanto, la voluntad de los dioses la que da salida a una situación a la que no se le veía la salida, pues allá en Tebas había quedado Edipo, cegado pero ya consciente de todo, algo similar a lo que estaban sufriendo los expedicionarios en los campos de Troya, incapaces de hallar una salida a la situación. Y aquí, en Edipo en Colono, Sófocles da un paso más al introducir a través de la proyección de un cuadro fruto de imágenes convergentes de dos pasados, uno remoto y otro próximo, pero ambos idealizados, una salida a una situación cerrada y desprovista de esperanza, dando con ello Sófocles testimonio postrero del gran amor a su polis y de su fe en ella, en los atenienses, una fe que, a pesar de todo, en ningún momento perdió.

Hay un innegable paralelismo entre Edipo, que creyó elevarse a lo más alto por sí mismo, que creyó ser artífice de su propio destino, encarnación trágica de aquellos hombres que canta el estásimo primero de Antígona, capaces de alcanzar las más altas metas, de realizar las más sublimes hazañas, siempre al límite del abismo, como al final del mismo estásimo se advierte, y aquellos atenienses que gozando de un reconocido prestigio en el mundo griego, pero al mismo tiempo imbuidos de una fe ciega en sí mismos, se embarcaron en una política expansionista ${ }^{58}$ que les ha llevado a la situación en la que se en-

${ }^{58}$ Son interesantes las reflexiones de Tucídides sobre la línea política de Pericles y de sus sucesores con relación a los sucesos de Sicilia, a los que dedica los libros 6 y 7, sobre los que pudo 
cuentran, destrozados por la guerra y por las tensiones internas agudizadas por las consecuencias del desastre de Sicilia ${ }^{59}$. En la persona de este Edipo de Edipo en Colono, ciego y desgraciado pero finalmente purificado de sus errores y salvado, Sófocles crea un paradigma que invita a los atenienses a repensar su polis reencontrando la armonía cívica perdida. No se puede, en nuestra opinión, disociar Filoctetes de Edipo en Colono: el primero es un canto a la armonía de todos los sectores atenienses, en el segundo, ante la inminencia del desastre total, nos habla del lugar en el que se hace realidad el imaginario colectivo ateniense, un lugar de donde se debe sacar fuerzas para volver a ponerse en pie. Relacionado con ese llamamiento a aunar esfuerzos, a tomar consciencia de que la gravedad de la situación exige la superación de divisiones y diferencias para lograr el concurso de todos los atenienses sin distinción, está también la focalización del Ática en el demo de Colono, que en la memoria reciente de los espectadores estaba relacionado con los sucesos que siguieron al desastre de Sicilia, frente a los que Sófocles no permaneció indiferente $e^{60}$, y que desembocaron en el golpe del 411.

tener información directa de espartanos y siracusanos, ya que desde el 424 estaba en el exilio. Debió de redactar estas reflexiones después del 404. Primero, recuerda el consejo del que Pericles hacía depender el éxito: el no aspirar a nuevos dominios. Después señala los muchos errores

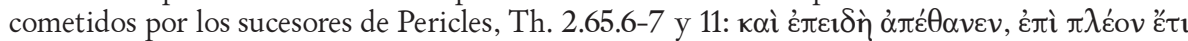

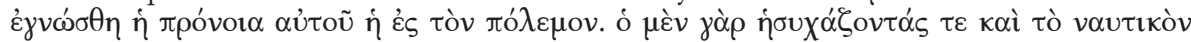

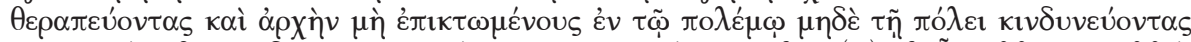

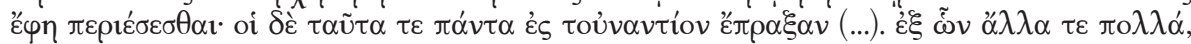

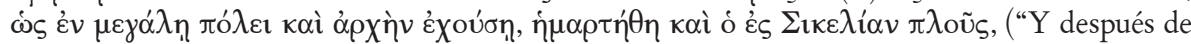
su muerte aún más fue reconocida la clarividencia de sus previsiones respecto a la guerra. Pues afirmaba, en efecto, que si permanecían tranquilos y se cuidaban de su flota y la arqué no la acrecentaban durante la guerra y no ponían en peligro a la pólis, saldrían bien librados. Pero con relación a todas esas cosas actuaron en sentido contrario (...). A partir de lo cual otros muchos errores, como era de esperar en una pólis grande y poseedora de una arqué, fueron cometidos y la expedición a Sicilia"). Aunque en esta parte de su obra Tucídides se ocupa de la expedición a Sicilia del 415-413, esta expedición es presentada como la culminación de una serie de errores fruto de la línea política seguida por los sucesores de Pericles al abandonar los principios que habían regido la política de aquél.

${ }^{59} \mathrm{La}$ derrota del 413 en Sicilia fue de tal envergadura que resultó decisiva. Como señala J.K. Davies al comienzo del capítulo siete, el que dedica a la "Guerra del Peloponeso" en La democracia y la Grecia clásica, Madrid 1981, 116: “entre los años 413-411 se produjo una verdadera pausa, cuando la superioridad ateniense había sido quebrantada. Persia intervino en la guerra y Esparta se convirtió en una potencia naval. A partir de entonces la nueva configuración de la política internacional siguió estable durante una generación, hasta la década del 370 , y los finales concretos de las guerras en el 404 y en el 386 fueron comparativamente poco importantes. Por lo tanto, aunque parezca poco ortodoxo, terminar este capítulo en el 413 y extender el capítulo ocho desde el año 412 al 380 concuerda con los hechos militares y políticos”. Si el proceso iniciado en el 413 hubiera cuajado, los atenienses no hubieran llegado a la situación del 404, muy diferente a la del 411, como señala Cl. Mossé, Histoire d'une démocratie: Athènes, Paris 1971, 99: "L'ennemi était présent, prêt à soutenir les adversaires de la démocratie. Et parmi ces derniers, les "extrémistes», ceux qui rejetaient en bloc le régime et ses faiblesses, avaint tiré la leçon de leur échec de 411 et n'entendaient pas se laisser arrêter par des formes juridiques".

${ }^{60}$ Fue en Colono donde se reunió la Asamblea que en el 411 estableció la constitución de los 
Sófocles, al cantar a Colono como lo hace, ha recordado el ataque del espartano Agis contra Atenas en el 407 y la derrota que la caballería tebana sufrió precisamente en Colono ${ }^{61}$, lo que dio pie a que fuentes tardías hablasen de una milagrosa aparición de Edipo en el campo de batalla apoyando a los atenienses; de este modo se produce una vinculación muy estrecha entre el pasado mítico y el pasado reciente en una proyección esperanzada hacia el futuro. En este proceso Sófocles no olvida a la diosa Afrodita, estrechamente vinculada a Teseo, como tampoco olvida a aquellos héroes de viejo cuño, ahora recuperados, encarnados en Filoctetes y renovados y proyectados al futuro en el joven Neoptólemo, el hijo de Aquiles.

En dos obras alejadas cronológicamente, en las que se entona un canto de alabanza a Atenas, compuestas y representadas en momentos clave de la historia de los atenienses, dos autores tan diferentes como Eurípides y Sófocles cantan a una Afrodita cuyos poderes tienen efectos positivos para Atenas, y a través de esos efectos proyecta Sófocles la imagen no excluyente, sino integradora, de una realidad ateniense posible y deseada. El empleo en Edipo en Colono de un epíteto tan peculiar como xpuøóvios en un canto en el que se está destacando la importancia de la protección divina de la que gozan los atenienses, ayuda a evocar el papel protector que en época arcaica tuvo la diosa y del que, sin duda, quedaba recuerdo entre los atenienses en diversos ritos y lugares de culto.

400, como refiere Th. en 8.67. Con el traslado de la Asamblea fuera del núcleo urbano se buscaba dar al acto una mayor solemnidad celebrándolo en un santuario, el recinto sagrado de Colono Hípico, una pequeña colina situada a unos dos kilómetros del núcleo urbano (Paus. 1.30.4); esa distancia, escasa, resta peso a otro género de motivaciones, aunque no las excluya por completo. Con todo, esta coincidencia en la localización ha sido esgrimida como un argumento más por aquellos que sitúan a Sófocles en posiciones contrarias a la democracia, cuando no abiertamente oligárquicas, fruto las más de las veces de no haber entendido que sus posicionamientos son los de un tragediógrafo y, sobre todo, los de un ateniense fiel a su polis que se esfuerza por actuar con la independencia de criterio que las circunstancias y su arte le permiten, y, sobre todo, con una gran coherencia consigo mismo, un ateniense que ama a su polis, a la que nunca abandonó, ni en los momentos más difíciles; por ello, como señala Lesky, La tragedia griega, 191, "se comprende también que le encontremos como miembro de la corporación de los diez "próbulos» que, después del desastre de Sicilia (413), había de constituir en la democracia, que se resquebrajaba, un elemento de autoridad salvadora"; y de ello informa Arist. Rh. 1419a 26-31:

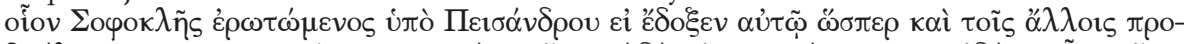

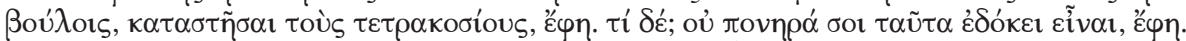

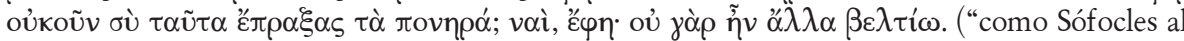
ser preguntado por Pisandro si le parecía bien, como a los demás próbouloi, que se estableciesen en el poder los cuatrocientos, dijo que sí. ¿qué? ¿no te parece que eso es una mala acción? dijo que sí. ¿Entonces tú has cometido esa mala acción? Sí, afirmó, puesto que no era posible otra mejor"). Con independencia de su exactitud, esta información nos da la imagen que de él quedó, la de un ateniense siempre dispuesto a contribuir a la buena marcha de su polis, incluso en los momentos más difíciles.

${ }^{61}$ D. S. $13.72 .3-4$. 